\title{
LEADERSHIP OF HEADMASTER IN GIVING EDUCATIONAL MANAGEMENT IN HIGH SCHOOL NAHDLATUL ULAMA (SMKNU) TULUNGAGUNG
}

\author{
Soim \\ STKIP PGRI Tulungagung \\ Email: soim_alkassi@yahoo.com
}

\begin{abstract}
Empowerment activities are considered the most appropriate choice to prepare the educational personnel in an effort to answer the challenges of the times. This research used qualitative research. Data collection used participant observation, in-depth interviews, and documentation. Data analysis starts from reduction, presentation, and conclusion. Data validity is done by the extension of attendance, triangulation, peer discussion and clarification with the informant. The results of research, 1) leadership of the principal in the empowerment of educational personnel using situational approach, this is evidenced by the principal always guiding, fostering, and assist his subordinates in the development of himself; 2) The headmaster in motivating the empowerment of his/her education personnel has the right trick to give motivation to the education personnel in performing various duties and functions. 3) Principal Strategy as an effort of empowerment of education personnel, principals provide opportunities for education personnel to improve their profession through upgrading, training, seminars and workshops, continue the study, requirement plan of education personnel, provide motivation of educational staff, pay attention to the welfare of educational staff, implement cooperation with educational staff and companies or other institutions in the implementation of school programs, fostering discipline of educational personnel.
\end{abstract}

Keywords: principal leadership, empowering educational staff

\section{INTRODUCTION}

National education is undergoing a number of fundamental changes, which are expected to solve various educational problems, both conventional and emerging problems with the coming of new ideas. The change is expected to create a conducive climate for improving the quality of education and empowering educational personnel. Change and development remain a top priority in the empowerment of educational personnel, among them in stimulating the role of teachers and staff to implement and develop a career coaching system.

Empowerment in the world of education is a very practical and productive way to get the best results from principals, teachers and employees and the process to achieve the best and productive results is to share the professional responsibility of teachers and other employees. One important principle in this empowerment is to involve teachers and other employees in the decision-making process and responsibilities, through this empowerment process is expected to educators have confidence (Mulyasa, 2007: 24).
In order to perform its roles and functions as a leader, the principal must have appropriate strategies to empower educational personnel through cooperation or cooperation, provide opportunities for education personnel to improve their profession and encourage the involvement of all education personnel in various activities that support the school program.

Empowerment activities are considered the most appropriate choice to prepare the educational personnel in an effort to answer the challenges of the times. Empowerment can make the school personnel become powerful in their profession. As principal many strategic steps can be taken to empower educators. In carrying out their duties and work, teachers (and teachers) in schools will need the encouragement and motivation of their leaders because this is a very important capital so that almost every action and policy taken by a leader has a positive and negative impact on the subordinates he leads.

Qualified educational personnel will not materialize well without being empowered properly. Empowered educational personnel means that the 
educational staff is upgraded to professional skills and then given a proportional authority because the characteristic of empowerment is essential To give ability or enable and to give authority. That way the education personnel will be in an open atmosphere, open in developing the potential, creativity, and ability to improvise without being shackled by school rules that are usually applied rigidly. An open atmosphere can help to actualize them. Educational personnel who are in the open school's atmosphere, it appears the spirit of excitement is very high.

According Syafrudin (2005: 160) tasks of educational personnel are as follows: (1) The teacher is the executor of the core activities (core business) school is a learning process that will determine the quality of graduates; (2) Librarians are personnel who provide textual learning resource services to support academic/learning activities; (3) Laboratory staff is a personnel that supports academic activities/student learning on a laboratory scale as a continuation or prove various that have been learned through literature learning; (4) The administrative staff is a supporting activity so that academic activities/ learning in schools, both academic administration and non-academic administration can run well; (5) Gardener personnel school who support for the school atmosphere remains beautiful and the learning process can run smoothly; and (6) Security personnel is responsible for creating a school atmosphere to stay safe and in control.

Teachers can be divided into five categories: (1) Educators, consisting of mentors, examiners, teachers and trainers; (2) The functional staff of education, consisting of overseers, supervisors, researchers and developers in the field of education and librarians; (3) Technical personnel of education, consisting of the laboratory, and technician learning resources; (4) Education unit management personnel, consisting of school principals, directors, chairmen, rectors, and leaders of non-formal education units; (5) Other personnel who deal with managerial or administrative problems of education (Danim, 2002: 17-18).

Whereas in the Law of National Education System Number 202003 Chapter 1 on General Provisions Article 1, paragraph 5, which is intended with the educational staff is a member of society who devoted themselves and appointed to support the implementation of education. More clearly mentioned in Chapter XI Educators and Education Personnel Article 39 paragraphs 1 and 2 , it is mentioned that the educational staff has the task of administering, managing, developing, supervising, and providing technical assistance to support the educational process in the education unit. And qualified teachers who are teachers, lecturers, counselors, civil servants, tutors, widyaiswara, instructors, and other designations in accordance with the specificity in charge of planning and implementing the learning process, conducting guidance and training, and conduct research and community service especially for educators in college.

From these conceptions can be concluded that the intended educational staff can be divided into two, namely the functional education personnel and technician education personnel. Functional personnel is educational personnel who occupy functional positions is positions that in the implementation of their work rely on the expertise of academic education such as teachers, counselors, supervisors, curriculum experts and so on. While the technical personnel of education is the educational personnel who in the implementation of their work more required operational and administrative technical skills such as librarians, school laboratory personnel and so on.

Leadership is generally understood as a pattern of behaving leaders in demonstrating their leadership in interacting with their subordinates in order to achieve organizational goals. Leaders must be able to move and direct his subordinates in actualizing all forms of duties as a form of real implementation. In this study, the authors take several theories of leadership such as from Fusch (2015) and Bernardin (1993), who argued that to be an effective leader and able to carry out his leadership functions well there are several criteria, including: having intelligence, motivate subordinates, possess broad and authoritative insights, and emotional maturity. A strong and effective leadership style is a key component to any success in a company (Shah, 2017).

A good leader should always be able to motivate his subordinates in such a way that in carrying out their duties, educational staff (teachers and employees) will have a high 
effectiveness of work and is expected to produce satisfactory results, both for schools and teachers (teachers and employees) itself.

\section{METHOD}

The research method used is descriptive qualitative research approach using case study type. This case study approach the researcher uses on the grounds as suggested by Sevilla et. all in Abdul Aziz (1998: 2) because we will engage in deeper investigation and a more thorough examination of the behavior of an individual. In addition, case studies can also lead researchers to the smallest social units such as associations, groups, families, schools and other forms of social units.

Data collection techniques used in this study are: (1) Participant Observation; (2) Interview; (3) Documentation. Observation is interpreted as a systematic observation and recording of everything that appears on the object of research (Margono, 2005: 159). Observation method in this research is used to collect data related to the research focus. In this case, the researcher tried to make a systematic observation and recording of the symptoms that appear in Vocational High School Nahdlatul Ulama (SMKNU) Tulungagung. The implementation of observation technique in this research is using participant observation. The purpose of participant observation is to observe events as they occur in the field naturally. In this technique, researchers involve themselves or interact directly with the activities undertaken by the subject by collecting data systematically from the data required.

Interview method is the process of obtaining information for the purpose of research by means of question and answers while meeting face to side in question (Nasution, 2002: 113). Interview or interview method for this research is used as a guide in doing research. In this case, the researcher uses in-depth interview technique (in a deep interview), that is by digging deep information about headmaster's leadership in the empowerment of education staff. The researcher will interview the headmaster of Vocational High School of Nahdlatul Ulama (SMKNU) Tulungagung, and educational staff to obtain data about the principal's leadership strategy in the empowerment of educational staff.
Documentation method is a method used to find data about things or variables in the form of notes, transcripts, books, newspapers, agenda or so (Arikunto, 2006: 20). In one study, documentation techniques were used as a source of supporting data. In addition, documentation data is required to supplement data obtained from interviews and observations. Researchers, in this case use documentation techniques to obtain data in the form of archives, notes, books related to leadership strategy of principals in the empowerment of educational staff. The documents may include photographs, school documents, interview transcripts, and documents on the history of the school and its developments, to all of these documentations will be collected for analysis for the completeness of the research data. In this case, the researchers took photographs related to the leadership of the principal in the empowerment of educational personnel.

This research uses case study design, with data analysis technique According to Miles and Huberman (1992: 22), the analysis of qualitative research data can be done through three activities that simultaneously are: 1) data reduction, 2) presentation data (data displays and 3) conclusion drawing/verification. The working model of the analysis can be seen in the two pictures below.

To ensure the trust or validity of data obtained through this research, it is necessary to test the validity and feasibility of data conducted by: (1) Peer Discussion. Peer discussion is by temporarily exposing results or final results obtained in the form of analytical discussions with peers who have the ability, expertise in the field of education, related to the principal's professionalism. Discussion of colleagues is done by discussing the data and research findings during the researchers in the field, researchers will discuss again the data obtained, both with teachers and principals. Through this peer discussion, it is expected to contribute a lot, in this study. (2) Data Triangulation. Data triangulation activities are used to search for new information, to prove that the data already obtained is reliable data. Searching information about the same data, extracted from several different information and in different places. Using triangulation of this data means checking and comparing the level of trust or truth of information or data obtained by using various methods of data 
collection, ie by interview, observation, and documentation. This can be done in a way; (a) comparing observation data with interview data, (b) comparing interview result with document contents, obtained from documentation method.

(3) Triangulation of Data Sources. To test the validity of the data, triangulation of data sources is used, ie by comparing a phenomenon based on data obtained by the researcher, from time dimensions and other sources, for example by comparing data obtained through interviews with principals, with data obtained from teachers, or other education personnel. Triangulation of data sources is used to check data about principal leadership in empowering educational staff, including principal's motivation, principal's strategy, in the empowerment of education personnel. Triangulation of data sources is also used to resolve space and time constraints, and limit people as data sources.

\section{RESULT AND DISCUSSION}

\section{Result}

This research have result: First, The approach of principal leadership in the empowerment of educational staff at Vocational High School Nahdlatul Ulama (SMKNU) Tulungagung including into personal approach an institution, this can be seen from some leadership characteristics such as: (a) The principal in his leadership takes personal approach and agency and always prioritizes cooperation with subordinates to achieve common goals. (b) Principal Vocational High School Nahdlatul Ulama (SMKNU) Tulungagung when carrying out his leadership always see the circumstances and abilities of his subordinates.

The principal always cultivates a sense of kinship and unity and constantly strives to build enthusiasm and encourage his subordinates to do the work and to continue to develop his academic potential. The situational approach of leadership style tends to differ from one situation to another. There are leaders tend to direct (directive), always give instructions to subordinates, and there are also leaders who tend to give support (supportive). And in other situations, it may be a combination of a tendency to give direction and give support (Wahjosumidjo, 1987: 100).

Lead behavior can be defined as the extent to which a leader engages in one-way communica- tion. The form of direction in this one-way communication involves defining the role that followers should follow, tell followers what to do, how to do it, and strictly monitoring the followers. Supportive behavior is the extent to which a leader engages in two-way communication eg listening, providing support and encouragement, facilitating interaction and engaging followers in decision making (Toha 1995: 65).

Situational leadership is an approach to leadership that says that all leadership depends on circumstances or situations. In applying a situational approach, the principal should be based on an analysis of the situation at a particular point in time and identify the condition of the member or subordinate he leads. Subordinate conditions are an important factor in situational approaches because subordinates other than as individuals they are also groups that in fact can determine the personal power that the leader has.

In situational approach, it is important for every leader to make a good diagnosis of the situation. Understanding the situation here is to include time, job demands, subordinate ability, expectations, organizational goals and subordinate goals, and different motives (Wahjosumijo in Marpaung, 2014).

From the review, according to Wahjosumijo (2005: 30 ) that the situational leadership model contains the main ideas: (1) Where the leader is in performing his duties influenced by situational factors namely, the type of work, organizational environment, characteristics of individuals involved in the organization; (2) Effective leadership behavior is leadership behavior that is adjusted to the level of maturity of subordinates; (3) An effective leader is a leader who always helps subordinates in their development from not being mature to mature.

There are seven processes of maturation, namely: (1) Active $\rightarrow$ Passive; (b) Not hanging $\rightarrow$ Depend; (c) Able to do many ways $\rightarrow$ Able to carry out a few ways; (d) deep interest $\rightarrow$ d. Shallow interests; (e) Wide view $\rightarrow$ Short-term view; (f) Top positions $\rightarrow$ Subordinate positions; (g) Controlled and self-conscious $\rightarrow$ Lack of selfconfidence

Leadership behavior tends to differ from one situation to another. There are leader behaviors that tend to lead (directive) always give instruc- 
tions to subordinates, and there are leaders who tend to give support (supportive). Furthermore, in other situations, it may be a combination of both tendencies.

In line with these opinions, the leadership of Nahdlatul Ulama Vocational High School principal (SMKNU) Tulungagung in empowering educational personnel using situational approach, this is evident with the principal always guiding, fostering, and assisting his subordinates in the development of himself. And in taking a policy based on the existing situation. By looking at the different characteristics of educational institutions, institutional environment, and organizational goals.

Second, the motivation of school principals in the empowerment of educational staff at Vocational High School Nahdlatul Ulama (SMKNU) Tulungagung. The principal in motivating the empowerment of his / her education personnel has the right strategy to provide motivation to the educational personnel in performing various duties and functions. This motivation can be grown through: 1) regulation of the physical environment. The physical environment arrangements include conducive workspace, study room, library room, laboratory space, workshop, and arranging a comfortable and pleasant school environment. 2) setting work atmosphere. A quiet and pleasant working atmosphere will also inspire the performance of educational personnel. 3) discipline. Discipline is meant that in improving the professionalism of educational personnel in schools, the principal must try to instill discipline to all his subordinates. Through this discipline is expected to achieve the goal effectively and efficiently, and can increase school productivity. 4) encouragement. The success of an organization or institution is influenced by various factors, both internal and environmental factors. 5) awards. This reward is very important to improve the professionalism of the educational staff. Through this award, the education personnel can be stimulated to improve the professionalism of work in a positive and productive. Award rewards can be attributed to the achievements of educational personnel openly, so they have a chance to achieve them.

\section{Discussion}

Sudjana (2004: 236) states that procedures in the implementation of disciplinary control functions including effective supervision can be carried out in steps including: collecting information on current events, identifying problems, analyzing problems, finding and establishing alternative problem solving and implementing troubleshooting efforts.

Principal leadership strategy in empowerment of nursing staff at Vocational High School Nahdlatul Ulama (SMKNU) Tulungagung. The strategy of schooling as an effort to empower teachers at Nahdlatul Ulama Vocational High School (SMKNU) Tulungagung has many strategies that can be done by an educational leader to empower educational staff. Teachers are one of the factors that determine the success of teaching programs and school goals so that teachers are required to have professional skills in carrying out their duties. Therefore, the development of resources/potential that exists in the teacher, should always be done.

Principal Vocational High School Nahdlatul Ulama (SMKNU) Tulungagung understands his strategic position as an educator, leader, organizer, innovator, manager and supervisor. The roles are then manifested in the effort of empowerment of nursing staff at Vocational High School Nahdlatul Ulama (SMKNU) Tulungagung namely: a) principals provide opportunities to educational personnel to improve the profession through upgrading, training, seminars and workshops, b) the principal gives encouragement and opportunity to educate staff to continue the study, c) principal pay attention to the plan of the need for education personnel clearly, d) headmaster provide motivation of educational staff to improve work productivity, e) pay attention to the welfare of educational staff, $f$ ) and other companies or institutions in the implementation of school programs, g) guidance of the discipline of educational personnel.

The principal is one component of education that plays a role in achieving school vision and mission. The principal is responsible for the successful implementation of educational activities by implementing the empowerment of his subordinates. In addition, the principal is responsible for the quality of human resources, 
especially teachers in the direction of expected professionalism, so that they are able to carry out the task of education well. In this case, the principal is in charge of carrying out the functions of leadership, both functions related to the achievement of educational goals and the achievement of a conducive school climate.

The principal is the top leader in the school, the principal must have the right strategy in empowering the educational staff. An organization or educational institution always wants its personnel to perform their duties optimally and contribute their full potential to the interests of the organization or educational institution, and work better than the day. In addition, the employees and other subordinates also need improvement and improvement on him included in the task. In this regard, the function of coaching and employee development is a function of personnel management that is absolutely necessary to improve, maintain and improve employee performance. This empowerment can be done in various ways. Coaching and development activities are not only about the aspect of ability but also concerning career employees.

In addition, in order to empower educational personnel required employee appraisal system objectively and accurately. The assessment of educational personnel is focused on individual achievement and participation in school activities. For employees, valuation is used as feedback on various issues, such as ability, precision, shortcomings and potential which in turn are used for determining career goals, pathways, plans and development (Mulyasa, 2005: 101).

Many ways can be done for the empowerment of educational staff. But it all goes back to the human factor that runs it. Therefore humans who are in the educational environment must have the will to always evolve. In order to implement the empowerment of education personnel, the principal must have an appropriate strategy in empowering educational personnel through cooperation or cooperative, providing opportunities for educational personnel to improve their profession and encourage the involvement of all education personnel.

Empowering educational personnel through cooperation or cooperation in the intention that in improving the professionalism of educational personnel in schools. The principal should prioritize cooperation with education personnel and other relevant parties in carrying out each activity.

Provide opportunities for education personnel to improve their profession. In this case, the principal must be democratic and provide opportunities to all educational personnel to develop themselves optimally. For example, by giving opportunities to subordinates to follow educational activities such as upgrading, workshops, seminars are adjusted to the field.

As according to Yayat Hayati Djatmiko (2005: 54) stating that: The characteristic of a democratic leader in decision-making is reflected in his actions to include subordinates in the whole decision-making process. Maintenance of this democratic type of relationship gives a strong emphasis on a harmonious relationship, in the sense of maintaining a balance between formal and informal relationships.

A democratic leader tends to treat his subordinates as co-workers, also maintaining a balance between task-completion orientation and relational relationship orientation. Encouraging the involvement of all education personnel, it is intended that the principal should endeavor to encourage the involvement of all educational personnel in every activity in the school. This is important to develop a sense of ownership of the education personnel of the school in which they perform their duties.

Meanwhile, according to Castetter as quoted by E Mulyasa (2005: 103), the implementation of strategies in the development of educational personnel can be identified into general strategies and special strategies. General strategy includes the development of education personnel related to, 1) The development of educational personnel should be done based on a clear need plan, 2) In the world of education should always develop the attitude of professional skills, 3) Cooperation with education with the company needs to be developed, especially in utilizing company for laboratory practice and object study.

A special strategy is a strategy that is directly related to the development and improvement of the management of more active educational personnel. The strategy relates to welfare, pre- 
service education of candidates for education personnel, recruitment and placement, the guidance of education personnel (Mulyasa, 2005: 128).

Increasing the professionalism of the educational staff and the development of the existing potentials of educational personnel in schools, principals should strive to instill the discipline of educational staff. Through this discipline is expected to achieve goals effectively and efficiently, and can increase school productivity.

Adjustment of a conducive physical environment and a good working atmosphere setting will foster motivation of educational personnel in carrying out the task. Therefore, the principal should be able to improve the motivation of educational personnel in order to perform their duties optimally and should be able to create harmonious working relationships with the educational staff, as well as creating a pleasant environment.

Development of education personnel can be done with attention to his welfare. This is related to the compensation given by the school to the education personnel. Compensation is a reward for a given service that can be valued with money and has a fixed tendency to be given. The issue of compensation is one form of reward that must be met. Because the rewards of the workers are no longer seen as a means of satisfying their material needs, they are already associated with human dignity and prestige.

Lazaruth (1984: 69) states that material and spiritual well-being is a major factor affecting the height of low morale, with the fulfillment of material and spiritual well-being, one will work effectively and energetically. Efforts to pay attention to the welfare of the educational staff, the principal must pay attention to the mental and spiritual welfare of the educational staff and have appropriate strategies to reward and reward the service to the education personnel by paying attention to the standard of education personnel needs and strive to provide better compensation and attractive.

Based on these opinions, the effort that has been set by the head of Vocational High School Nahdlatul Ulama (SMKNU) Tulungagung in the empowerment of educational personnel is an effort in carrying out its functions and role as a leader of an educational institution to develop, improve skills, skills and knowledge of carry out their duties and achieve school success in realizing the established goals.

The strategy that has been done by the head of Vocational High School Nahdlatul Ulama (SMKNU) Tulungagung, it is understood that the principal has a strong effort in empowering the educational staff, and it implies that the effort that has been done by the principal has partly to the development of potential or resources human beings by trying to create a comfortable situation and conditions and a good and balanced working relationship with educational staff or related institutions.

\section{CONCLUSION}

Headmaster's in empowerment of nursing staff at Vocational High School Nahdlatul Ulama (SMKNU) Tulungagung determines leadership style based on the situation and condition faced by the principal. With the meaning of the principal in using the leadership style tailored to the situation at hand principal.

Empowerment of education personnel, head of Vocational High School Nahdlatul Ulama (SMKNU) Tulungagung, when acting always see the circumstances and abilities of his subordinates. The headmaster also always try to approach the person and institutions and always prioritize cooperation with subordinates to achieve common goals. He always cultivates a sense of kinship and unity and constantly strives to build enthusiasm and encourage his subordinates to do the work and to continue to develop his academic potential.

Motivation of principals in the empowerment of educational personnel in Vocational High School Nahdlatul Ulama (SMKNU) Tulungagung can be grown through: (a) regulation of the physical environment. The physical environment arrangements include conducive workspace, study room, library room, laboratory space, workshop, and arranging a comfortable and pleasant school environment; (b) setting work atmosphere. A quiet and pleasant working atmosphere will also inspire the performance of educational personnel; (c) discipline to achieve the goal effectively and efficiently, and can increase the productivity of school; (d) encouragement both internal and environmental factors; (e) awards. Through this award, the education personnel can be stimulated to improve the professionalism of work in a 
positive and productive.

Principal Vocational High School Nahdlatul Ulama (SMKNU) Tulungagung understands his strategic position as an educator, leader, organizer, innovator, manager and supervisor. The roles are then manifested in the effort of empowerment of nursing staff at Vocational High School Nahdlatul Ulama (SMKNU) Tulungagung namely: a) principals provide opportunities to educational personnel to improve the profession through upgrading, training, seminars and workshops, b) the principal gives encouragement and opportunity to educate staff to continue the study, c) principal pay attention to the plan of the need for education personnel clearly, d) headmaster provide motivation of educational staff to improve work productivity, e) pay attention to the welfare of educational staff, f) and other companies or institutions in the implementation of school programs, g) guidance of the discipline of educational personnel.

In an effort to empower educational staff, the principal is advised to fully understand and implement the function and role of educator, manager, administrator, supervisor, leader, innovator and motivator. And the principal is advised to always try and have the right strategy to foster and develop the potential that exists in educational personnel.

In order to empower teachers, teachers and school staff are encouraged to attend training coaching, and seminars are held both at school and outside the school, always developing the competencies held in accordance with the times, and trying to always generate motivation, especially motivation which comes from the educational personnel themselves, which will affect the desire to always develop themselves.

To the future researchers are expected to research on the principal's leadership, to be studied more deeply with various other research methods in order to obtain new discoveries that can be utilized by the educational institution in achieving the goal.

\section{REFFERENCES}

Arikunto, Suharsimi. 2006. Prosedur Penelitian: Suatu Pendekatan Praktik. Jakarta: PT Rineka Cipta.

Aziz, A. 1998. Memahami fenomena sosial melalui studi kasus: kumpulan materi pelatihan metode kualitatif. BMPTSI Wilayah VII Jawa Timur, Surabaya.

Bernardin, H. John and Russel, Joice E.A. 1993. Human Resources Management An Experimental Approach. McGraw Hill, Inc.

Danim, Sudarmin. 2002. Inovasi Pendidikan "Dalam Upaya Peningkatan Profesionalisme Tenaga Kependidikan”, Bandung: Pustaka Setia,

Djatmiko, Yayat Hayati. 2005. Perilaku Organisasi. Bandung: Alfabeta,

Fusch, Patricia I. 2015. Leadership and Conflict Resolution on the Production Line. International Journal of Applied Management and Technology 2015, Volume 14, Issue 1, Walden University, LLC, Minneapolis

Lazaruth. 1984. Kepala Sekolah dan Tanggung Jawabnya. Salatiga: Yayasan Kasinius.

Margono, S. 2005. Metodologi Penelitian Pendidikan Cet V, Jakarta: Rineka Cipta.

Miles M.B dan Huberman A.Mikel, 1992. Qualitative Data Analisis. Beverly Hills: SAGE Publication, Inc.

Mulyasa, E. 2005. Menjadi Kepala Sekolah Profesional, dalam Konteks Menyukseskan $M B S$ dan KBK, Bandung:Remaja Rosdakarya,

Mulyasa, E. 2007. Standar Kompetensi dan Sertifikasi Guru, Bandung: Remaja Rosdakarya,

Nasution. 2002. Metodologi Research Penelitian Ilmiah, Jakarta: Budi Aksara,

Shah, Muslim. 2017. Impact of Interpersonal Conflict in Health Care Setting on Patient Care; the Role of Nursing Leadership Style on Resolving the Conflict. Nurse Care Open Acces J 2(2): 00031. DOI: 10.15406/ ncoaj.2017.02.00031

Sudjana, H.D. 2004. Manajemen Program Pendidikan: Untuk Pendidikan Nonformal dan Pengembangan Sumber Daya Manusia. Bandung: Falah Production.

Toha, Miftah. 1995. Kepemimpinan dalam Manajemen, Jakarta, Raja Grafindo Persada, cet VI,

Marpaung, M. (2014). Pengaruh kepemimpinan dan Team work Terhadap kinerja karyawan Di koperasi sekjen kemdikbud senayan jakarta. Jurnal Ilmiah Widya, 1(1). 